\title{
Still an unknown topic: child abuse and "shaken baby syndrome"
}

\author{
Hala bilinmeyen bir konu: Çocuk istismarı ve \\ "Sarsılmış Bebek Sendromu"
}

\author{
Elçin BALCI, ${ }^{1}$ İskender GÜN, ${ }^{1}$ Şule MUTLU ŞARLI, ${ }^{1}$ Fatma AKPINAR, ${ }^{1}$ \\ Fatih YAĞMUR, ${ }^{2}$ Ahmet ÖZTÜRK, ${ }^{1}$ Osman GÜNAY ${ }^{1}$
}

\section{BACKGROUND}

Shaken baby syndrome (SBS) is a severe form of physical child abuse, and can even cause death. In this study, we aimed to investigate whether or not the primary healthcare workers had received any education regarding child abuse and neglect, whether they could diagnose the cases, whether they had sufficient knowledge about SBS as a part of child abuse, and whether they were in need of education on the topic.

\section{METHODS}

Health workers in the primary healthcare centers in the province of Kayseri were enrolled. A questionnaire was applied.

\section{RESULTS}

In this study, $35.0 \%$ of the study group were physicians. $43.7 \%$ of the study group stated that they had not recieved any education regarding child abuse and neglect, and $52.1 \%$ stated that they believed that physical abuse was the most prominent form of abuse in society. While $64.1 \%$ of the participants stated that they had heard about SBS, $10.4 \%$ of these stated that they had heard about it, but did not have adequate knowledge on the topic.

\section{CONCLUSION}

There is a lack of knowledge and a need for education regarding child abuse and neglect among the personnel working in primary healthcare, especially on the subject of SBS. Undergraduate and postgraduate education regarding child abuse and SBS will help to increase the number of people well-informed and sensitive to this important issue.

Key Words: Child abuse; education; health personnel; in-service training; shaken baby syndrome.

\section{AMAÇ}

Sarsılmış bebek sendromu (SBS) çocuğa yapılan fiziksel istismarın ciddi bir formu olup ölüme dahi sebep olmaktadır. Bu araştırmada birinci basamak sağlık çalışanlarının çocuk istismarı ve ihmali konusunda eğitim alıp almadıkları, istismar olgularını tanıyıp tanıyamayacakları, bir istismar türü olan SBS konusunda bilgili olup olmadıklarının araştırılması amaçlandı.

\section{GEREÇ VE YÖNTEM}

Araştırma kapsamına Kayseri birinci basamak sağlık kuruluşlarında hizmet veren sağlık personeli alındı. Katılımcılara anket uygulandi.

\section{BULGULAR}

Araştırma grubunun \%35,0'i hekimdi. Grubun \%43,7'si daha önce çocuk istismarı ve ihmaline ilişkin herhangi bir eğitim almadıklarını, \%52,1'i toplumda en çok fiziksel istismarın görüldüğünü düşündüklerini ifade etti. Katılımcıların \%64,1'i SBS'yi daha önceden duymuş olduğunu söylerken; duyanların \%10,4'ü duyduğunu ancak bilmediğini ifade etti. İstismar konusuyla ilgili eğitim alma durumu meslek grupları arasında anlamlı olarak farklı bulundu.

\section{SONUÇ}

Çocuk istismarı, ihmali ve istismarın bir alt başlığı olan SBS konusunda, birinci basamak sağlık personelinin bilgi eksiği ve eğitim ihtiyacı vardır. Mezuniyet öncesi ve sonrası eğitimlerde çocuk istismarı ve SBS konularına yeterince yer verilmesi farkındalık ve duyarlı birey sayısının artmasına yardımcı olacaktır.

Anahtar Sözcükler: Çocuk istismarı; eğitim; sağlık personeli; hizmet içi eğitim; sarsılmış bebek sendromu. 
Intentional or unintentional behavior by an adult that affects a child's health or psychosocial and physical development negatively is defined as child abuse. Child abuse is classified into four groups as: neglect, physical abuse, sexual abuse, and emotional abuse. ${ }^{[1]}$ Primary healthcare workers, who should give priority to preventive medicine, have an important responsibility for educating society, and for diagnosing, reporting and preventing possible abuse cases. In order to educate and advise society regarding child abuse, these health workers should possess the necessary knowledge and acquirements on this topic in addition to general health issues. ${ }^{[2]}$ If an abused child is not diagnosed when first brought to the center and sent back home, this abuse will most likely continue and can even result in death. ${ }^{[3]}$ The insufficiency in undergraduate and postgraduate education regarding child abuse complicates the physicians' diagnosis of an abused child and prevents its consideration within the differential diagnosis. ${ }^{[4]}$

Shaken baby syndrome (SBS) is a severe form of physical child abuse, first defined by pediatric radiologist John Caffey in 1946. It is a syndrome that presents with cerebral hemorrhage, retinal hemorrhage and/or fractures (especially posterior rib fractures), resulting from being shaken by an adult, grabbed by the arms or body. Due to the weakness of the neck muscles, there is an excessive movement of the head during this shaking movement, which in turn leads to tearing in the cortical bridge veins, which traverse from the cortex to the dural venous sinus.

The diagnostic triad for SBS is accepted as subdural hemorrhage, retinal hemorrhage and encephalopathy. ${ }^{[5,6]}$ Among the children exposed to abuse, SBS ranks first in the etiology of death especially in children aged $0-4$ years. ${ }^{[7,8]}$ The signs and symptoms show a wide range from trivial signs such as anxiety, shaking and

Table 1. Distribution of the study group according to some descriptive characteristics

\begin{tabular}{lcc}
\hline Characteristics & Number & $\%$ \\
\hline Profession & & \\
$\quad$ Physician & 229 & 35.0 \\
$\quad$ Nurse & 79 & 12.1 \\
$\quad$ Midwife & 228 & 34.9 \\
$\quad$ Others (Health officer, & & \\
$\quad$ Environment technician, etc.) & 118 & 18.0 \\
Gender & & \\
$\quad$ Male & 245 & 37.5 \\
$\quad$ Female & 409 & 62.5 \\
Marital status & & \\
$\quad$ Married & 581 & 88.8 \\
$\quad$ Single & 55 & 8.4 \\
$\quad$ Divorced + Widowed & 18 & 2.8 \\
Total & 654 & 100.0 \\
\hline
\end{tabular}

vomiting, to severe signs such as lethargy, convulsions, coma, stupor, and even death. Twenty percent of the cases are usually lost within a few days following the trauma. There is still a serious lack of knowledge in society regarding the hazards created by SBS. ${ }^{[9]}$

In this study, we aimed to investigate whether the primary healthcare personnel have received any education regarding child abuse and neglect, whether they can diagnose it, whether they are aware of SBS as a form of child abuse, and whether better education on the topic is needed.

\section{MATERIALS AND METHODS}

\section{Study Group}

This study was performed in April 2010, and 729 primary healthcare personnel working in the province of Kayseri were enrolled. As it was aimed to reach the whole universe, sampling was not done.

\section{Data Collection}

A questionnaire developed for the study, which comprised 34 questions covering sociodemographic characteristics, educational status regarding child abuse, and their attitude, behaviors and knowledge regarding SBS, was completed via face-to-face method and by the investigators. Eleven personnel who were not on duty during the investigation (on leave, ill, etc.) and 64 who did not accept to participate were excluded. The study was completed with 654 participants (participation rate $89.7 \%$ ).

Their knowledge regarding child abuse and their educational status were evaluated by the participants' own statements. Knowledge about SBS was evaluated by the response to the question inquiring about the diagnostic triad. Those who gave the correct answer were accepted as being well-informed about SBS. The questions about the signs and medical investigations were open-ended with more than one choice.

\section{Analysis}

Data were evaluated by computer, following the questionnaire application, and chi- square test was used for statistical evaluation, with values of $p<0.05$ accepted as significant.

The necessary administrative permission for the study was obtained from the Provincial Directorate of Health, with ethical approval from Erciyes University.

\section{RESULTS}

The study was completed with 654 participants. $35.0 \%$ of the study group were physicians, $62.5 \%$ were female, and $88.8 \%$ were married (Table 1). $43.7 \%$ of the group stated that they had not received any education regarding child abuse and neglect. $52.1 \%$ of the group thought that physical abuse was the most commonly seen form of abuse in society. $53.5 \%$ of the 
Table 2. The general awareness of the study group regarding shaken baby syndrome

\begin{tabular}{lcc}
\hline & Number & $\%$ \\
\hline Shaken baby syndrome & & \\
$\quad$ Has heard & 419 & 64.1 \\
$\quad$ Has not heard & 235 & 35.9 \\
$\quad$ Total & 654 & 100.0 \\
Level of knowledge about SBS (n: 419) & & \\
$\quad$ Good & 92 & 14.1 \\
$\quad$ Poor & 260 & 39.6 \\
$\quad$ Has heard, but does not know & 68 & 10.4 \\
$\quad$ Total & 419 & 64.1 \\
Knowledge about the SBS diagnostic & & \\
triad (n: 352) & & \\
$\quad$ No & 186 & 28.4 \\
Yes & 166 & 25.4 \\
Total & 352 & 53.8 \\
Ability to diagnose SBS cases (n: 352) & & \\
$\quad$ Yes & 102 & 15.6 \\
$\quad$ No & 30 & 4.6 \\
Undecided & 220 & 33.6 \\
Total & 352 & 53.8 \\
\hline
\end{tabular}

group stated that they would determine abuse cases if encountered, and $99.6 \%$ thought that this topic was very important.

$86.6 \%$ of the participants thought that abuse could be prevented with education (87.8), law enforcement (4\%) and by increasing the interest (2.6\%). While $64.1 \%$ of the participants (n: 419) stated that they had heard about SBS, 10.4\% (n: 68) of those stated: "I have heard of it but I do not know what it is" (Table 2).

The educational status regarding child abuse differed significantly between professions. While $71.9 \%$ of the midwives stated that they had received postgraduate education, $75.4 \%$ of health personnel other than physician-midwife and nurse had never received any education on this topic.

The rate of correct responses to the question about the diagnostic triad of SBS was again significantly different between professions. While $55.5 \%$ of the physi- cians had answered correctly, $60.0 \%$ of the midwives and $69.7 \%$ of the other personnel did not respond correctly to the diagnostic triad question (Table 3 ).

$42.3 \%$ of the group stated that they thought that the most common person causing SBS would be the stepmother, followed by the biological mother (19.8\%). $42.2 \%$ of the participants answered the question "Should SBS be reported?" as: "It should be reported to the police and to the prosecution office"; $4.1 \%$ did not know to which agency abuse should be reported.

When their usual mode of cuddling a baby was questioned, $13.1 \%$ of the participants stated that they liked to cuddle babies harshly, bouncing them and making them cry. In response to the question "If someone shows their affection to your baby harshly, how would you intervene?", 63.6\% answered: "I would be angry, take the baby away, and warn them".

The participants who responded correctly regarding the SBS diagnostic triad stated that they liked to cuddle babies gently without battering them, and this was significantly different from those who did not know the correct answer $\left(X^{2}: 9.976, \mathrm{p}<0.05\right)$. There was no difference in the response to "If someone cuddles your baby harshly, what would you do?" between those who knew the diagnostic triad and those who did not, and they all answered that they would take their child away, become angry and tell the offender $\left(X^{2}\right.$ : 4.984, $\mathrm{p}>0.05)$.

\section{DISCUSSION}

Of the whole group, $43.7 \%$ stated that they had not received any education regarding child abuse and neglect. In a study performed by Yağmur et al. ${ }^{[2]}$ in Kayseri among primary healthcare workers, it was established that $83.4 \%$ of the healthcare workers did not have any education regarding child abuse and neglect. The difference between studies may be due to the contribution of in-service training courses in the meantime, which increased the number of people who received education.

Physicians should be able to: diagnose the signs and symptoms of child abuse and neglect with the hope

Table 3. Distribution of the rate of knowledge about the SBS diagnostic triad according to professional groups

\begin{tabular}{lcccccc}
\hline & \multicolumn{2}{c}{ Does not know } & \multicolumn{2}{c}{ Correct answer } & \multicolumn{2}{c}{ Total } \\
\cline { 2 - 7 } Profession & Number & $\%$ & Number & $\%$ & Number & $\%$ \\
\hline Physician & 73 & 44.5 & 91 & 55.5 & 164 & 100.0 \\
Nurse & 21 & 52.5 & 19 & 47.5 & 40 & 100.0 \\
Midwife & 69 & 60.0 & 46 & 40.0 & 115 & 100.0 \\
Other & 23 & 69.7 & 10 & 30.3 & 33 & 100.0 \\
Total & 186 & 52.8 & 166 & 47.2 & 352 & 100.0 \\
\hline
\end{tabular}

$X^{2}: 10.695 ; \mathrm{p}<0.05$. 
of not skipping any child abuse cases; evaluate medically the injuries these can cause; and take the necessary and emergent precautions in order to prevent any further damage to the child. ${ }^{[4,10]} 53.5 \%$ of the participants stated that they could diagnose child abuse cases when encountered. The educational status regarding child abuse was significantly different between professional groups. It was established that, while $62.5 \%$ of those who received undergraduate education and $35.0 \%$ of those who received no education at all were physicians, $45.6 \%$ of those who received postgraduate in-service training were nurses. Although they are deficient in undergraduate education, it was seen that nurses are more reachable with in-service training courses. This fact emphasizes the need to motivate physicians to participate more in in-service trainings and other meetings and educational activities in order to progress in their profession. In addition, the fact that health workers other than physicians, nurses and midwives are the group least informed regarding child abuse and SBS is very striking, and points to the need to prioritize their education.

While $52.1 \%$ of the group thought that physical abuse was the most common form of abuse in society, according to a study regarding child abuse in Turkey, emotional abuse is the most frequent form. ${ }^{[11]}$ The fact that there are visible concrete physical signs and symptoms in physical compared to emotional abuse, resulting in examination by a physician, may be the reason for this misinterpretation. Improved awareness and knowledge about child abuse and neglect, a correct diagnosis and meticulous notification will provide true interpretations on this topic, with more precise numbers.

Child abuse is a crime, and these cases should be reported as soon as possible to the prosecution office, social services or hospital security. ${ }^{[12]}$ While $42.2 \%$ of the participants stated that SBS should be reported to "police stations, police or the prosecution office", $4.1 \%$ did not know the appropriate avenue for reporting the abuse. Keeping in mind that lack of knowledge does affect attitude and behaviors, it was noticed that even if these cases are diagnosed, notification is usually disregarded.

$64.1 \%$ of the participants stated that they had heard about SBS before, but of these, 10.4\% stated: "I have heard about it but I am not well-informed". Knowledge about SBS, the reporting of deaths due to SBS and scientific literature knowledge are insufficient in other countries as well. ${ }^{[13]}$ This situation may be due to insufficient awareness of this topic, and the fact that it has gained in importance only recently.

$42.3 \%$ of the group stated that they would suspect the "real/biological" mother as the probable offender.
In the literature from abroad, the biological father or the new partner of the mother was reported as the more common suspect. ${ }^{[9,13]}$ Due to the sociocultural structure of our country, this interpretation based on the experiences and observations of health personnel may be assumed to be correct, considering that fathers usually abstain from embracing their children, especially in infancy. The mothers are usually responsible for the care of the baby, and stepmothers, who also become responsible for the child automatically, may not be as caring as the biological mothers. Furthermore, any traumatic or violent behavior from the father is usually accepted as natural in our society, thus excluding fathers from ranking first as the abusers. However, the fact that divorce rates and the number of step-parents that join the family by remarriage are also lower in our country should not be overlooked.

When the baby cuddling habits of participants were queried, $13.1 \%$ stated that they cuddle harshly, bouncing infants up and down and making them cry. Those who were aware of SBS liked to embrace babies more gently, perhaps because knowledge about a topic creates a change in people's attitude and behavior, causing them to be more gentle. This is quite promising, in the sense that any educational and informational efforts will have a good result, and individuals will exhibit greater care while caressing or showing love to a child. The response to the question "What would you do if someone showed their love to your baby harshly" was the same by both those who were and were not aware of child abuse, with both groups stating that they would remove their child, and this may be perceived as reflecting a protective instinct.

In conclusion, primary healthcare workers have inadequate knowledge on the topic of SBS, a form of child abuse and neglect, and there is a real need for education. Providing enough education through undergraduate and postgraduate trainings on child abuse and SBS will increase awareness on this topic, as well as the number of people who become sensitive to possible cases. Overcoming the lack of knowledge facilitates an improvement in attitude and behavior, and is promising for obtaining a better and gentler approach to babies and improving how they are shown love and affection. Early diagnosis and treatment of SBS cases will prevent complications, and forensic notification will intimidate people and help to prevent the development of new cases.

We also believe that there is a need for extensive education and investigation among people actively involved with children other than health personnel, such as parents, teachers, and caregivers, etc.

It should not be forgotten that diagnosing the cases, recording any possible signs of abuse, reporting abuse, 
and providing medical treatment are legal responsibilities, apart from the medical aspect; physicians and all health personnel should be educated, and parents and teachers should be well-instructed in this matter.

More studies and new case series will enable us to make better comments especially regarding the differing risk factors in our country.

\section{REFERENCES}

1. Dubowitz H. Preventing child neglect and physical abuse: a role for pediatricians. Pediatr Rev 2002;23:191-6.

2. Yağmur F, Balcı E. Kayseri ili merkez ve ilçeleri birinci basamak sağlık çalışanlarının, çocuk istismarı ve ihmali konusunda bilgi düzeyleri: Anket çalışması. Adli Bilimler Dergisi 2009;8:7-11.

3. Kirschner RH, Wilson H. Pathology of fatal abuse. In: Reece RM, Ludwing S, editors. Child abuse medical diagnosis and management. 2nd ed. Philadelphia: Lippincott Williams \& Wilkins; 2001. p. 503-5.

4. Yağmur F, Asil H, Canpolat M, Per H, Coşkun A. Kısa mesafeli düşme ve sarsılmış bebek sendromu. Türkiye Klinikleri J Med Sci 2010;30:766-71.

5. Akar T. (Shaken Baby Syndrome). Çocuk istismarı ve ihma- line multidisipliner yaklaşım. 1st ed. Ankara: Ankara University Press; 2006. p. 47-53.

6. Ulukol B. Sarsılmış bebek sendromu. Türkiye Klinikleri J Pediatr Surg-Special Topics 2008;1:28-36.

7. Rimsza ME, Schackner RA, Bowen KA, Marshall W. Can child deaths be prevented? The Arizona Child Fatality Review Program experience. Pediatrics 2002;110:11.

8. American Academy of Pediatrics: Committee on Child Abuse and Neglect. Shaken baby syndrome: rotational cranial injuries-technical report. Pediatrics 2001;108:206-10.

9. Ward MG, Bennett S, King WJ. Prevention of shaken baby syndrome: Never shake a baby. Paediatr Child Health. 2004;9:319-21

10. Önal Ç. Çocuk istismarı. Türkiye Klinikleri J Pediatr Sci 2007;3:27-9.

11. Turhan E, Sangün Ö, İnandı T. Birinci basamakta çocuk istismarı ve önlenmesi. Sürekli Tıp Eğitimi Dergisi (STED) 2006; 15:153-7.

12. Hancı İH, Eşiyok B. Child abuse and legal arrangements in penal code. Türkiye Klinikleri J Pediatr Sci 2006;2:91-3.

13. Matschke J, Herrmann B, Sperhake J, Körber F, Bajanowski T, Glatzel M. Shaken baby syndrome: a common variant of non-accidental head injury in infants. Dtsch Arztebl Int 2009;106:211-7. 